\title{
URBAN HERITAGE OF KABUL AND POST-WAR RECOVERY EFFORTS
}

\author{
B.A. KAZIMEE ${ }^{1} \&$ A.W. NAJIMI ${ }^{2}$ \\ ${ }^{1}$ School of Design and Construction, Washington State University, USA. \\ ${ }^{2}$ Aga Khan Trust for Culture, Afghanistan.
}

\begin{abstract}
The 30 years of tragic war that was imposed on Afghanistan has dealt a severe and destructive blow to the physical and social fabric of its cities. The regrettable victims in this conflict, however, that were entrapped are the historic cities where fierce street-to-street fighting inflicted utter destruction of some of the most valuable historic and residential buildings. Like many important urban and architectural heritage in the Islamic cities, historic Kabul evolved through continual cultural participation that entrusted deeper meanings to its architecture and urban form. Historically, Kabul with its wonderful traditional architecture of courtyards, lavish Timurid gardens, decorated worship centres and glowing historic bazaars that enticed trade enterprises and merchants around the region sustained a vibrant city life for its inhabitants. With an analysis and discussion of the importance of architectural and urban heritage of the city, the article illustrates the post-war efforts of local and international aid organizations and historical conservation processes. The article further reflects on revitalization of its architectural and urban heritage in the light of social and economic regeneration and cultural awareness.

Keywords: architectural heritage, conservation, residential fabric, socio-economic regeneration.
\end{abstract}

\section{HISTORICAL ANALYSIS AND URBAN DEVELOPMENT}

The historic city of Kabul contains a wealth of cultural repositories through its architecture and urban form that are the result of an evolving process of development through many generations. Being located on the major network of ancient trade routes, connecting India and China to the Persian trade routes and beyond to the west, the city represents eventful layers of historical accounts that are inherently important for its development.

From archaeological excavations, Kabul's original site can be traced near the slopes of the Chakari Mountain, which is located to the southeast of the present city, where Buddhist temples and irrigation canals are found [1]. It is believed that the growth of the city continued to the northwest for defence purposes. In the holy book of Rig Veda (circa 1200 BC), there is a mention of Kubha, which refers to Kabul River. Ancient explorers have observed in 675 AD that Kabul was an important strategic commercial and pilgrimage centre. Kabul at this time was protected by a defensive wall guarding the city on Sher Darwaza mountain noticeable to the west extending south-eastwards to Bala Hisar (the citadel) and the Asamaee hill to the present Deh-Afghanan mountain slopes. During this period Kabul was an agricultural community and its inhabitants were followers of Buddhism. In 698 AD, the Arabs invaded Kabul and after several decades, they finally managed to capture Kabul, and as a result, the city suffered from significant devastations of the war. Years later, the inhabitants of Kabul accepted Islam as their new religion and with it new socio-cultural values and administration techniques [2].

In 1502 AD Zahiruddin Muhammad, later known as Babur Shah, the Mongol emperor, established Kabul as his capital. Babur Shah was very fond of Kabul and he commissioned

This paper is part of the Proceedings of the International Conference on Islamic Heritage Architecture and Art (Islamic Heritage Architecture 2016)

www.witconferences.com 
various construction projects including beautiful gardens and several buildings. In $1739 \mathrm{AD}$ Kabul suffered from the invasion of the Iranian King Nader Shah Afshar, and some of the city's buildings and gardens were destroyed. Nader Shah facilitated the settlement of his ethnic Qizilbash group in the Chendawol district of the Old City and built a separate wall around this district. Soon however, it was retaken by the Afghan King Ahmad Shah, the founder of modern Afghanistan, and the capital was established in Kandahar. After his death in $1773 \mathrm{AD}$ his crowned son Timur Shah transferred the capital from Kandahar to Kabul, primarily because of its central location and lesser number of tribal conflicts [2, p. 13]. During his period Kabul grew in prosperity and in population as the capital of the kingdom. The city maintained its social and cultural cohesiveness and the residential quarters were known by tribal and clan names. The livelihood of the inhabitants depended on nearby agricultural land and trade activities within the city.

Later, in the years 1839-1842 AD due to conflict with the belligerent British Army, Kabul was devastated. Many of its fine architecture and urban fabric were destroyed, including the great Char-Chatta Bazaar which was one of the finest commercial establishments in the region. The bazaar was burned by the British Army in retaliation for their defeat. The CharChatta Bazaar was a famous commercial centre; its merchandise has been mentioned by early travellers, thus reflecting the important strategic location of Kabul between East and West [3]. The population of Kabul at this time was estimated to be around 50,000.

The size of the city in the 19th century remained very much the same and it possessed most elements of a traditional Islamic city. Fortification walls still enclosed the city; and the entrance to the city was controlled by several gates. Many commercial bazaars and series were the hub of city life. Access to the city from across the Kabul River, which was located to the north of the Old City, was provided by various bridges, many of which are still in use.

It was only during the later part of the 19th century that the sheer richness of urban dynamics of the Old City was eclipsed by the implementation of modern city planning schemes sanctioned by the rulers outside the Old City boundaries. During the rule of Amir Abdur Rahman, the new city expanded north-west and underwent great physical transformation. The Amir built opulent palaces for himself outside the city, such as Arg (the citadel), Baghe-Bala and Chilsoton palaces, as well as the Arg Bazaar, and several other ornate mansions inside spacious gardens, with elaborate architectural and landscape schemes to proclaim his royal position. It was also at this time that the Amir authorized the building of a public water system for the city. The water was diverted from an upstream Kabul River and was channelled by an underground tunnel system throughout the city. At every major street intersection, an iron gate was provided that led through a stairway to the supply channel where the inhabitants accessed their water needs. It was during the reign of Habibullah his son (1901-1919) that the first piped water supply system was introduced to the city of Kabul, where the system was in use till the war in the 1970s. The water was channelled to the city from a reservoir located in Paghman about 17 miles to the west of the city at the southern slopes of Hindu Kush mountain. The population of Kabul at this time was estimated to be around 160,000. Like his father, King Habibullah commissioned several additional lavish palaces and public buildings and introduced electricity and piped water supply to the city. He built the Dilkusha palace, expanded the Arg and built the Eidgah mosque and Habibia College [3].

The modernization of Kabul further intensified during the reign of his son King Amanullah (1919-1929), who was determined to modernize and bring rigorous reforms to the country's socio-economic structure. He established his new power seat at Darul-Aman, located six miles southwest of the Old City, where a grandiose parliament building was built in the elegant 18th-century European-style architecture designed by a French architect [4]. Insistent with his 
modern project, a comprehensive plan was developed by French architects and German engineers for the new city. The plan called for a modern city that included provision for necessary public buildings, educational facilities, health centres, commercial and sumptuous westernstyle residential subdivisions, with many elegant gardens and open spaces for the leisure of citizens. A railway line was established to connect the Old City to the new capital for the movement of materials and people. Telephone services were introduced in Kabul for the first time and the capital was connected to the outside world via air traffic [5]. Amanullah, through his modernization scheme, laid the foundation for modern planned urbanization. Many of his plans were followed by King Nader Shah and his successor King Zahir Shah. Kabul University was established in the early 1930s, and in the 1940s, the city began to grow as an industrial centre. In the 1960s, the city was largely developed as a big cosmopolitan centre [5].

The antecedent planning philosophies promulgated fragmented and heterogeneous patterns of development in newer areas of the city. The modernization project of the late 19th century and the desire for western-style modern subdivisions resulted in further marginalization of the historic city, which resulted in its population being deprived of social and economic support of the government as it turned a blind eye. The consequential gentrification of the historical fabric not only inflected damaging effect to the diversity and heritage of the historical areas but also created a rift between the rich and poor, upper elite and lower class stratum, with negative consequences.

In 1962 under a national economic development plan, a team of planners was invited from the Central Scientific and Research Design Institute for Town Construction of the USSR to prepare a new 25-year master plan for the city of Kabul [6]. The plan called for a total population of 1.5 million and took into account further population growth and migration from rural areas. Ironically, the plan had earmarked the entire site of the Old City as a slum area that was to be replaced by new multi-storeyed apartment blocks similar to Soviet-style four-storey prefabricated housing blocks given the nomenclature of 'Micro-Ryan'.

The 25 years of war had another distressing blow to the properties and infrastructure of the historic city. The inter-factional street fighting of 1993-1994 reduced much of the traditional physical fabric to rubble and the Old City became an uninhabitable locality. However, it was in 2002 that an appropriate rehabilitation and conservation programme was formulated that encouraged the resettlement process and allowed for reconstruction and repair of war-damaged properties. Between 2003 and 2005 the population of the city showed a 15\% increase mainly due to the resettlement of displaced families whose homes were damaged by war [7]. With the availability of marginal public services and very basic infrastructure, the area attracted many more migrant population from the rural areas and elsewhere who found affordable living and access to casual employment in the area. Recent statistics on historic quarters report significant population increase and the highest residential densities in the Old City reported to be around 250 people/ha, with most traditional homes subdivided and sublet over time [7].

\section{POST-WAR CONSERVATION AND REHABILITATION PROCESS}

In the aftermath of the 2001 military campaign in Afghanistan, an ambitious reconstruction programme was formulated by national and international organizations. Recognizing the need for the protection of historical urban heritage and cultural sites, though not a priority, meagre funding for architectural conservation work was allocated in the early stages of the reconstruction process. Initially the funds were provided by the Greek, US, Canadian and UK governments and the World Bank resources, channelled through the Aga Khan Trust for Culture foundation and its Historic Cities Programme (HCP). Since 2002, the activities of the HCP in close collaboration with community leaders, municipal representatives and the 
Ministry of Urban Development played an important role in the urban recovery of the Old City of Kabul as well as providing support for the conservation and reuse of historic properties across the country.

Under the initiative of urban conservation and in an effort to stabilize the fragile urban fabric of the Old City, the Aga Khan Trust for Culture focused on upgrading the surrounding infrastructure in the poorer neighbourhoods and on repairing the war-damaged homes, to allow for the resettling of its displaced population. In the spirit of capacity-building and institutional reform, in 2006, the Turquoise Mountain Foundation initiated conservation work in the district of Muradkhaneh, located north of the Kabul River, where a craft training centre has been established, as part of efforts to promote employment of Afghans [8]. Under these programmes many craftsmen and artisans were trained in the traditional techniques of building construction, carpentry and other artisan trades to help and be employed in their communities. The foundation also supports home-based activities that will help develop the skills of female members of the household such as tailoring, embroidery and gelim-weaving - all of which have the potential to contribute to improve the livelihoods of the people. The scope of these programmes is widely acknowledged now and the HCP programme has benefited more than 50,000 people across the country and provides sustained employment opportunity for many Afghans [9].

The conservation work in the Old City has helped the residents to become aware of the need for safeguarding their historical urban heritage and seems to have effectively heightened awareness of citizens in heritage value and the historical pride invested in their neighbourhoods [10] (Figs. 1 and 2).

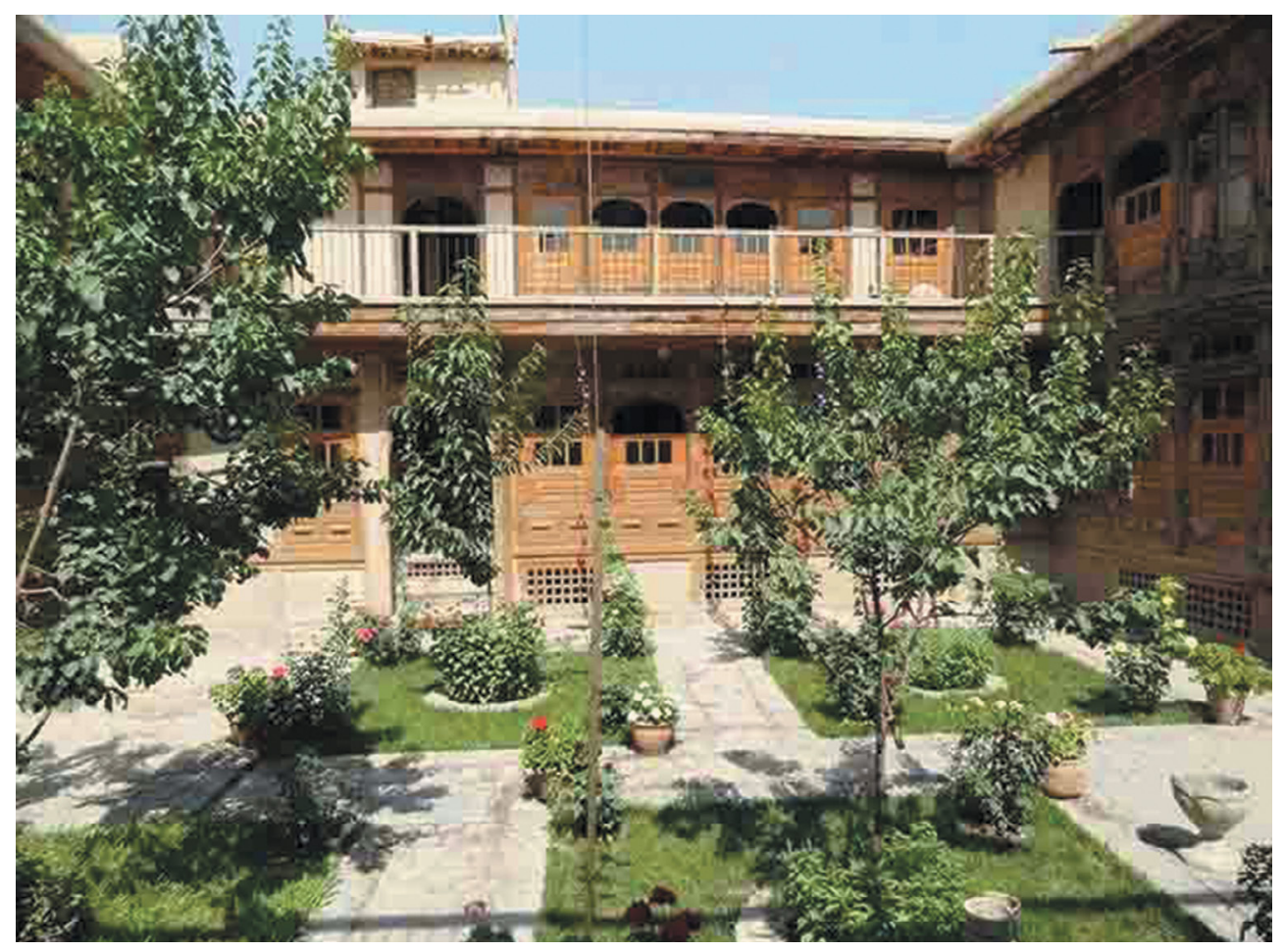

Figure 1: Traditional courtyard house in the Muradkhaneh region of the historic city. Restoration initiated by Turquoise Mountain Foundation conservation programme. 


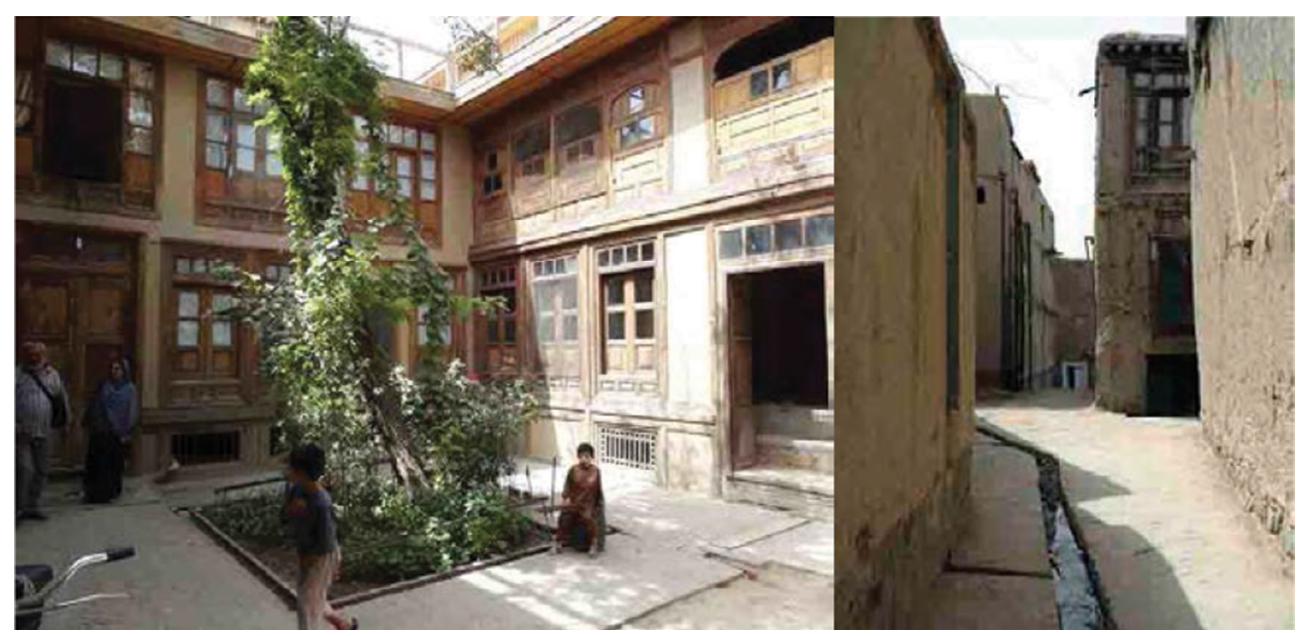

Figure 2: Traditional courtyard house and alleyway in the Ashiqan-wa-Arifan region of the historic city. Restoration initiated by the Aga Khan Trust for Culture foundation and its Historic Cities Programme (HCP).

\section{THE NEED FOR CONSERVATION OF HISTORIC QUARTERS}

\subsection{Cultural expression and the value of heritage}

Historic Afghan cities throughout centuries of its existence supported a way of life and a very splendid urban expression that came from a profound philosophical and religious background. Like many Islamic cities the new architectural style and urban development in Kabul pursues a modernist style of architecture that does not provide the charm of traditional Afghan places and lacks much regional fit. Traditional Afghan cities and architecture are the product of centuries of development which have a direct bearing on its regional identity and sense of place. People adapted to the forces of climate and geography that resonated values beyond pragmatic comfort, but which had a real-life impact on the shape and makeup of their built places. Traditional urban districts were identified by placid dense urban fabric endowed with much aesthetic appeal and distinguished cultural history. The role of the historic city of Kabul is critical for benefiting from the value of heritage. Urban designers and architects need to make careful analysis of the Old City's urban attributes and carefully formulate them into coherent strategies for newer developments. By working with stakeholders, embarking on educational programmes and implementing sound design and planning policies, designers can establish their desired vision for future developments [11].

\subsection{Housing needs and heritage areas}

The task of providing adequate housing for the growing population in the city is extremely challenging, especially when the rate of rapid urbanization due to migration and population growth which has a direct implication on the provision of shelter and security is reaching its critical point. Kabul is facing acute housing problems and is not able to cope with the impact of this significant population growth. There is no evidence that the problem of shelter will 
subside any time soon. The historic city of Kabul continues to provide viable and affordable shelter for the majority of people in this area, especially the poorer segment of the population. Upgrading the infrastructure and providing minimum amount of services (with much lower costs for the whole development) is easy for the authorities rather than pricey investment options in newer subdivisions. The housing prototype that characterizes the historic city is the introverted courtyard houses which closely fit the cultural aspiration of the population and is easily adaptive to changing needs and desires of the families. With many variations the courtyard houses are instrumental in providing affordable accommodation to the growing housing needs of the population.

\subsection{Economic role of heritage}

The Old City also played an active role in catering to the needs of commerce and culture of not only its own population but also the merchants and trade throughout the region. Its importance has been prominent and described by the intensity of commerce, cultural and administrative vitality. The city has had some of the richest economic and cultural resources that influenced its underlying urban fabric. The urban structure was intertwined with many ancient bazaars, commercial series and religious establishments. These important economic and cultural establishments are necessary to be revitalized in order to rejuvenate and restore the status and prestige of the Old City. The present observation already shows an immense concentration of commerce and merchant activities following its ancient and pre-war entrepreneurial spirit.

\subsection{Tourism industry and heritage}

In recognizing the growing interest of global population in the field of tourism, conservation of the Old City will add essentially important economic, social and cultural dynamic to the city and will bring stimulus to the marketing of heritage products for the benefit of heritageseeking tourist population. Traditional architecture, combined with a rich arts and craft heritage of Afghanistan, has been an important source of pride and devotion for its people and the demand for its articles in the international market has been an important spur behind the local industry and its market in the region. Creating and reviving the craft techniques and designs in the Old City will support the production and distribution of hand-made Afghan crafts worldwide including traditional Afghan woodwork, jewellery, ceramic, textile and calligraphy, endowing a source of pride and vocation for families.

\subsection{Educational and research opportunities}

Preserving the architecture and urban structure of the historic city of Kabul represents more than a nostalgic longing for the past and ways that have essentially became obsolete, but rather a learning place by which larger challenges such as sustainability, housing crises and economic equality can be addressed. The historic city buildings provide us with a large repository of natural and cultural heritage that illustrates a genuine and symbiotic relationship with the spirit of this unique place. This relationship that is the true expression of knowledge and wisdom is a valuable lesson for the mainstream architects and urban planners to design new human settlements in the country. The meaningful environment of the Old City provides 
a wealth of knowledge for the professionals and academic institutions in the country and elsewhere to do their research and scholarly explorations. It also endows great inspiration for other multidisciplinary scholars, such as those in the social sciences, ethnography, and urban economy, to seek a multitude of their research and scholarship needs.

\section{CONCLUSION}

Revitalizing the historic city will not only improve the economic status of the area but also enhance the social conditions of its inhabitants who now occupy the historic district. Among the important resources in the city is the motivation and skills of the population that have to be mobilized in a massive scale. Studies show that many of the active workforce living in the Old City find employment in construction-related jobs or small-scale production industry. Harnessing the abilities of those who have some skills especially in the traditional building techniques of masonry, carpentry and building repair, we can find a range of talents that could bear important benefits for the conservation and reconstruction process.

Traditional building technologies and materials will continue to present the reality of affordable shelter for the majority of people in the city. This is because people take advantage of self-help process and participatory approaches to build their shelter, which is most economical and within their means of affordability. Building with local materials and incrementally improving their houses are within their affordable means to accommodate their growing family needs. Setting up of a self-help building advisory service by the government to encourage higher standards of construction is a very effective approach in keeping the reconstruction process unrelenting [12].

Government and aid organizations can assist in small financing schemes over long periods of time for residential buildings, secured by the dwelling and land values. Housing cooperatives and lending organizations that are secured by government guarantees can be more effective in providing financial help to individuals for restoration and repair to improve their dwellings [13]. The government should provide help with the provision of infrastructure and services (such as sewer, water, electricity, education and health facilities on these sites), which also may require incremental development in stages as funds become available.

Courtyard house form which is widely used in the Old City is an excellent shelter prototype employing favourable climatic strategies for comfortable living of the families.

The layout and architecture of the courtyard houses are strongly affected by the Islamic culture and lifestyle, seeking to establish privacy and identity for the families. The houses are inward looking and open to a central garden. They are of varied sizes and range from one to three stories in height. Traditionally the courtyards included several living quarters which accommodated larger numbers of extended families. The repair of many of these houses damaged or abandoned by the population during the war can provide an affordable shelter choice, which is already conducive to the lifestyles of the inhabitants. In addition, the restoration and revitalization process will build confidence among the community members and leaders in the Old City to commit to safeguard their valuable surviving historical heritage.

There is greater need for conservation and survival of rich historical and cultural heritage in Kabul as it contributes to the cultural asset of the entire country. The historic city built and restored to its original splendour will certainly provide great opportunity and stimulus for the economy and foster a familial sense of place where people take ownership of their built environment and live with dignity. 


\section{REFERENCES}

[1] Wolfe, N.H. \& Kohzad, A.A., Kabul, an Historical Guide to Kabul, The Education Press: Kabul, pp. 5-7, 1965.

[2] Arifi, A.G., Urban Policies, Planning and Implementation in Kabul, Afghanistan, UMP Dissertation Service, A Bell \& Howell Company: Ann Arbor, MI, USA, pp. 8-10, 2001.

[3] Schinasi, May, Kabul iii. History from the 16th century to the accession of Zāher Shah, Encyclopaedia of Iranica, Bibliotheca Persica Press: New York, Vol. XV, Fasc. 3, 19 April 2012, pp. 303-306, available at: http://www.afghanculturemuseum.org/portraitzafar-paiman/, accessed: Wednesday, 2 September 2015.

[4] Schadl, M., Development of Kabul: reconstruction and planning issues, eds Mumtaz, Babur \& Noschis, Kaj, 10th Architecture \& Behaviour Colloquium, Monte Verita, Ascona, Ticino, Switzerland, April 4-7, p. 16, 2004.

[5] Chua, A., The Promise and Failure of King Amanullah's Modernization Program in Afghanistan. The ANU Undergraduate Research Journal, Volume Five 2013, ANU Press: Canberra, Australia, pp. 35-36, 2014.

[6] Gopalakrishnan, R., The Geography and Politics of Afghanistan, Concept Publishing Company: Delhi, 1982.

[7] Najimi, A.W. \& Leslie, J., Urban recovery: the case of historic Kabul. Heritage and Sustainability in the Islamic Built Environment, ed. Kazimee, R., WIT Press: UK, pp. 23-37, 2012.

[8] Tang, A., Kabul's old city gets a new look. New York Times, 1 February 2008.

[9] Najimi, A.W., Building Kabul: Mimar, Architects and Engineers, Federal Institute of Technology Lausanne (ENAC, EPFL)/AKTC, 2004; Parametro: Rome, p. 272, 2007.

[10] Leslie, J., Hidden Kabul, Afghanistan Research Newsletter, Afghanistan Research and Evaluation Unit, Kabul, 2009.

[11] Kazimee, B.A., Sustainable reconstruction and planning strategies for Afghan cities: conservation in culture and environmental heritage. The Sustainable City - IV: Urban Regenerative and Sustainability, eds U. Mander, C.A. Brebbia \& E. Tiezzi, WIT Press: UK, pp. 49-60, 2006.

[12] Brebbia, C.A. \& Tiezzi, E., The Sustainable City IV: Urban Regeneration and Sustainability, WIT Press: UK, 2006.

[13] Cotton, J.R., Financing help for home restorations. The Old House Journal, available at http://www.oldhousejournal.com/ (accessed 2 September 2015). 